\title{
THE THEOLOGIAN WHO IS HOMELESS
}

\section{How PeOple Who ARE Homeless CAN CONTRIBUTE TO SPIRITUAL Growth at Their Parish ChUrCH*}

\author{
PETER VAN DER SLUIJS ${ }^{\dagger}$
}

\begin{abstract}
In A Theology of Liberation, a classic text of liberation theology, Gustavo Gutierrez "describes two strands of poverty in the Bible." One is material poverty which is a "scandalous condition against which to be indignant." The other is poverty as "spiritual childhood, humility before God," which means "total availability to the Lord" and "an ability to receive." seeking to address the material poverty of people who are homeless, the Church of England is failing to recognise its own need to humbly receive. ${ }^{2}$ The experience of being homeless and sleeping rough on the street provides those who have undergone it with a spiritual perspective worth hearing. In its efforts to alleviate the distressing and uncomfortable situation in which people who are homeless find themselves, the Church neglects to stop and listen to the voices of those that they are seeking to help. As a result, not only do those perspectives get lost, but the Church unintentionally further marginalises and stigmatises people who are homeless by reinforcing their powerlessness. Only by being open to being transformed by the presence and perspectives of outsiders, such as people who are homeless, can the parish church become a community that models God's love in the world, and give a foretaste of the heavenly city.
\end{abstract}

\section{Introduction}

$\underline{\text { Plan and Structure of Study }}$

I am going to root my discussion in the Church of England because of its unique position in the life of the nation. As Ken Leech points out "the close links with monarchy, aristocracy and establishment, with national identity and state, are inextricably elements of a dominant Anglican history." At the same time, the parish system gives Anglican theology "a view of pastoral care

* (C) 2021 Peter van der Sluijs

${ }^{\dagger}$ MLitt 2021 University of St Andrews

${ }^{1}$ Gustavo Gutierrez, A Theology of Liberation, trans. Sister Caridad Inda and John Eagleson (London: SCM Press, 1974), 299.

${ }^{2}$ I will use 'Church' to refer to the Church of England, and 'church' to refer to a local congregation or the church generally.

${ }^{3}$ Kenneth Leech, The Sky is Red (London: Darton, Longman and Todd, 1997), 58-9. 
which extends beyond the confines of the congregation."4 I will show that Church members take this pastoral responsibility seriously and see addressing material poverty as part of their Christian calling, undertaking considerable work with people who are homeless. However, my research question turns this issue on its head. Its grammatical structure makes people who are homeless the subject, taking the action of contributing. The parish church is the direct object - the recipient, rather than the provider, of assistance. The assistance envisaged, grammatically the indirect object of the verb contribute, is spiritual growth. It is important to note that there are two levels of listening to people who are homeless. The first, as Laura Stivers pithily puts it, is to give them "a defining voice in the process" of meeting their needs, to avoid compounding their victimization with "our" solutions to "their" problems. ${ }^{5}$ The second is to be open to being transformed by them. As Jane Kopas points out, Jesus's “method of dealing with outsiders invites us to dialogue in imagination and fact with the marginalized to see what they can teach us about our own lives and values." ${ }^{6}$ Both matter, but it is the second that I will be seeking in this dissertation. I will show that if this form of listening is present, people with lived experience of homelessness can make valuable contributions to the teaching in the church not only through sermons or other forms of address, but also by their mere presence.

I am going to start by exploring the spirituality of people who are homeless. Having defined who these people are - a point of some controversy- I will ask if individuals with such overwhelming physical needs and problems are inclined to consider anything beyond the here and now? Do they think theologically and, if so, what form does their thinking take? Are there any distinctive features? I will then go on to consider how the Church of England responds to people who are homeless. I will show that negative attitudes to people who are poor / homeless found in society in general are prevalent amongst Church members too. As a result, the Church is excluding people who are homeless even as it seeks to address their needs. In fact, its charitable work can become a barrier to listening. By setting the views uncovered in the interviews alongside those of formal theologians, I will demonstrate that the perspectives of people who are homeless are valid and worth hearing. I will then show that mutual storytelling can break down stigmatisation and rebalance relationships, allowing a more inclusive church community to be built. I will conclude

\footnotetext{
${ }^{4}$ Id, 61.

${ }^{5}$ Laura Stivers, Distrupting Homelessness: Alternative Christian Approaches (Minneapolis: Fortress Press,

${ }^{6}$ Jane Kopas, "Outsiders in the Gospels: Marginality as a Source of Knowledge," The Way 33: 2 (1993), 124.
} 2011), 7. 
that only by embracing people who are homeless and listening to them fully can the parish church demonstrate its loyalty to the City of God.

Method

I will access the voices of people who are homeless mainly through published interviews. I will then examine Church of England responses to the urban poor (including people who are homeless) by looking at significant reports and comments from the Church itself, its leaders and other organisations such as Theos and the Church Urban Fund. I will conclude by considering the Church of England's response to people who are homeless in the context of Dorr's model of Integrated Spirituality.

\section{$\underline{\text { Relevance and Importance of Study }}$}

There are numerous substantial studies of spirituality amongst people who are homeless and their experience of life on the streets based on interviews with them. In addition, the extensive work that Christian organisations in general and the Church of England specifically undertakes with these people is well documented. There are also extensive considerations of the issue of homelessness, including the structural issues and the values in society that underlie it. There is room for a study drawing these three elements together, looking at the extent to which the Church has absorbed the values in society that lead to homelessness, how the spiritual perspectives of those experiencing it can help it resist them and, how, as a result, it can grow spiritually. This is the gap that this dissertation aims to fill.

\section{Literature Review}

My literature review will follow the overall structure of this article, looking at sources supporting the sections on the spirituality of people who are homeless, the attitude of the Church to them, the value of their perspectives, the role of mutual storytelling in overcoming stigmatisation and the vision of the parish church as a fully inclusive community equally embracing the prosperous and the marginalised.

The voices of people who are homeless

I start by seeking out the voices of people who are homeless themselves. To help define who these people are, I will rely on a 1992 paper by Chris Chamberlain and David Mackenzie on the definition of homelessness, which is regarded as normative by some of my other sources. ${ }^{7}$ This

7 Chris Chamberlain and David Mackenzie, "Understanding Contemporary Homelessness: Issues of Definition and Meaning," Australian Journal of Social Issues 27, no. 4 (November 1992), cited by Raelton Gibbs, 
paper explores the social norms underlying the definition of homelessness. Having established who and what it is I am talking about I will use three sets of interviews to uncover the voices of people who are homeless. Some of their subjects identify with a specific religion and others have none. These interviews were conducted by researchers in homeless shelters, day centres and on streets in cities in England. An important point is the independence of the interviewers from the care of their interviewees. Although two (David Nixon and Raelton Gibbs) were at some point involved in the management of homeless centres under the auspices of the Church of England and the Salvation Army respectively, they had relinquished those roles by the time the interviews took place. The third, Tamsen Courtenay, had no relationship at all with her subjects either before or after the interviews.

In Stories from the Street, David Nixon, a parish priest in Plymouth, England who has worked extensively with people who are homeless, presents 11 semi-structured interviews with men and women who have experienced homelessness. He uses them to "attempt to construct a theology of homelessness" and present a new telling of the Christian story. ${ }^{8}$ Nixon is a professional clergyman engaged by the Church of England, which he confesses occasionally leads to a defensive reaction to criticism. ${ }^{9}$ Since he groups extracts from the interviews thematically it is challenging to correlate the observations with the interviewees' biographies. Tamsen Courtenay, as an investigative journalist for the BBC's Panorama and Channel 4's Dispatches, by contrast is a professional storyteller. She makes this task easier by presenting the conversations she has pretty much verbatim. Her book, Four Feet Under, is born of the passion that she shares with Nixon for uncovering the stories of people who are homeless. She believes that their perceptions of the world are as valid as anyone's: "they see it all through a different prism." ${ }^{10}$ By contrast with Nixon, her interviews are unstructured, so there is considerable variation in the content. I will also use interviews conducted by Raelton Gibbs, for his doctorate. He has spent over 27 years as a Salvation Army Officer, working extensively with people who are homeless. The five individuals he speaks to have non-Christian spirituality at homeless centres in London. ${ }^{11}$ Gibbs speaks to each three

Staying in the Shadows: Faith, Homelessness and Troubled Lives, (London: University of East London and Tavistock and Portman NHS Foundation Trust, 2011), 50.

${ }^{8}$ David Nixon, Stories from the Street: A Theology of Homelessness (Farnham, Surrey: Ashgate Publishing, 2013), 149.

${ }^{9}$ Nixon, Stories, 103.

${ }^{10}$ Tamsen Courtenay, Four Feet Under (London: Unbound, 2018), 236.

${ }^{11}$ Gibbs, Staying in, 111. 
times and presents an extensive summary of the remarks of each before analysing their observations. Lastly, I turn to Bosede Owa, who became homeless in 2015 and received help from St John's Hoxton, a Church of England parish church in London. ${ }^{12}$ She now has a home for herself and her daughter, and has been appointed to a paid position as Pastoral Care Minister at this church. St John's offers one of her sermons on YouTube, delivered in September 2020. ${ }^{13}$

The role of the Church

An up-to-date survey of the work of the Church of England with people who are homeless can be constructed from a variety of sources. I will look at the 2020 Theos / CUF report Growing Good: Growth, Social Action and Discipleship in the Church of England. This report sets out to investigate the relationship between Church growth, social action and discipleship. ${ }^{14}$ Specifically, it seeks to address the paradox that the nation is increasingly reliant on Church social action but is "less and less spiritually connected to it." 15 I will apply the framework of "theology in four voices" developed by the ARCS (Action, Research, Church and Society) team, even though the report does not present the operant theology of Church work with people who are homeless. ${ }^{16}$ I consider the formal theology it draws on and the authorities it recognises as normative alongside the theology it espouses, and will look for consistency between the body of the report and its recommendations.

The 2017 Church in Action report produced by the Church of England and the Church Urban Fund (CUF) is the most recent review of Church of England social action including work with people who are homeless. ${ }^{17}$ Based on a survey of church leaders, it may overstate the activity that is taking place but even so the level of work it presents is impressive. There is insufficient detail to evaluate the prevailing character of this practice, but an earlier 2012 CUF survey, Bias to the Poor, is insightful. It uses data from the British Social Attitudes Survey to compare the attitudes of churchgoers on poverty related issues to the general population. ${ }^{18}$ To explore how the Church

${ }^{12}$ Hannah Rich, Growing Good: Growth, Social Action and Discipleship in the Church of England, Theos (London: Theos, 2020), 85.

${ }^{13}$ Bosede Owa, "Summer Psalms - Psalm 71," YouTube video, St John's Hoxton, accessed 3 December 2020.

${ }^{14}$ Rich, Growing Good, 19.

${ }^{15} \mathrm{Id}, 14$.

${ }^{16}$ Helen Cameron et al., Talking about God in Practice: Theological Action Research and Practical Theology (London: SCM Press, 2010), 51.

${ }^{17}$ Tom Sefton and Heather Buckingham, Church in Action: A National Survey, (London: The Church of England and Church Urban Fund, 2017).

${ }^{18}$ Church Urban Fund, "Key Findings: Bias to the Poor? Christian Attitudes to Poverty in This Country," accessed 10 December 2020. 
is addressing the attitudes of its congregations, I will look at the materials created by Housing Justice to support Homeless Sunday in October 2020. These include a sermon recorded by the Right Reverend Rob Wickham, its Chair (and the Bishop of Edmonton), as well as videos.

A vision for future Church social action in the field of housing is presented in Coming Home: Tackling the Housing Crisis Together, the report of The Commission of the Archbishops of Canterbury and York on Housing, Church and Community published in February 2021. Coming Home takes a wider view beyond the plight of people who are homeless to embrace those whose housing is sub-standard, insecure or overcrowded. ${ }^{19}$ Using the Church in Action report as its baseline for current church social action, it sets out a "positive vision for housing" and considers how the Church of England support it both as a major landowner and by resourcing its parishes. ${ }^{20}$ It also provides recommendations for Government and other stakeholders. ${ }^{21}$

\section{Spiritual Growth}

In the final three sections, I will look at the issue of spiritual growth. I will found my discussion on Donal Dorr's "Integral Spirituality" because he grounds it simply and effectively in the Bible (Micah 6:8). He notes that this verse calls on us to act justly, love tenderly and walk humbly. Dorr groups these different aspects of spirituality under three headings: the personal, the inter-personal and the public. ${ }^{22}$ He believes that many approaches to spirituality are inadequate because they concentrate on just one or two aspects, without taking into account the others or how they interlock. ${ }^{23}$ To develop each of these themes, I will turn to writers who have commented on the social justice issues around homelessness, on how stigmatisation acts as a barrier to the extension of love, and on why the Church lacks the humility to listen to them even as it professes to attend to their material needs. I will set these views alongside the voices that emerge from the interviews I present in the first section. Most of the interviews and the reports that I will draw on have been compiled in the last ten years, but some look back to Faith in the City and Faithful Cities, Church of England reports on its response to people who are poor, published in 1985 and 2006 respectively.

${ }^{19}$ Archbishop's Commission on Housing, Church and Community, Coming Home: Tackling the Housing Crisis Together (London: Church House Publishing, 2021), 12.

${ }^{20} \mathrm{Id}, 3$.

${ }^{21} \mathrm{Id}, 98$.

${ }^{22}$ Donal Dorr, Integral Spirituality: Resources for Community, Justice, Peace and the Earth (Gill and Macmillan: Dublin, 1990), 1.

${ }^{23} \mathrm{Id}, 3$. 
In my discussion on acting justly, I will draw on Pope Francis' recent encyclical Fratelli Tutti, published in October 2020, which offers "a new vision of fraternity and social friendship" to counter a culture of eliminating or ignoring others. ${ }^{24}$ Although he stands outside the Anglican tradition his thoughts on how the Christian concept of a neighbour should be reflected in the Church as a community present a valuable contrast to the views that emerge from the Church of England reports that I analyse. I will set his thinking on solidarity alongside that offered by Gustavo Gutierrez in his classic $A$ Theology of Liberation. ${ }^{25}$ I will show that solidarity implies listening at the second level I highlighted above and will therefore go on to consider the perspective of formal theologians on housing and homelessness alongside views that emerge from the interviews I looked at initially. An insightful collection of these perspectives is Coming Home: A Theology of Housing published by Church House in anticipation of the report of the Archbishop's Commission on Housing, Church and Community. ${ }^{26}$ Its editors and contributors include members of that Commission. Specifically, I will draw on the opening, framing article by Graham Tomlin, a member of the Archbishop's Commission, and a contribution by Nicola Harris and Jez Sweetland on the importance of community. I will show that its aim to "inspire some new approaches to housing" can be delivered by listening to people who are homeless as effectively as by the theologians who write in its pages. I will also draw on Christopher Button. As an academic theologian with experience of working with people who are homeless, he reflects "on homelessness in relation to belonging and identity." ${ }^{27}$ Again, I will set his views alongside those of individuals with lived experience of homelessness.

Then, in my consideration of "loving tenderly," I will turn to the importance of narrative theology and storytelling. To help understand narrative ethics, Nixon points to Arthur Frank's The Wounded Storyteller. Although focussed on stories of illness (including Frank's battle with cancer), it is, as Nixon points out, "easy to read across from disease to homelessness." ${ }^{28} \mathrm{He}$ characterises stories as restitution, chaos and quest narratives. I will use this as a lens through

${ }^{24}$ Francis, Fratelli Tutti: Encyclical Letter on Fraternity and Friendship, The Vatican Press (Vatican, 2020), paragraph 6.

${ }^{25}$ Gutierrez, A Theology.

${ }^{26}$ Graham Tomlin, "Coming Home: A Theology of Housing and Community," in Coming Home: A Theology of Housing, ed. Malcolm Brown and Graham Tomlin (London: Church House Publishing, 2020). To avoid confusion, I will refer to the report as Coming Home and the accompanying book as A Theology of Housing from this point.

${ }^{27}$ Christopher Button, "Where do I belong? Rethinking homelessness," Practical Theology 11, no. 2 (2018), 153.

${ }^{28}$ Nixon, Stories, 39, discussing Arthur Frank, The Wounded Storyteller (Chicago: The University of Chicago Press, 2013). 
which to consider the stories told by and about people who are homeless, and to understand both the power and the dangers of narrative theology, looking at examples from Growing Good, Nixon's Stories from the Street, and Wickham's Homeless Sunday sermon.

In the following section, I consider the Church as an idealised community modelling God's love to the world. To do this I will return to Fratelli Tutti as well as looking at On Human Worth by Duncan Forrester, ${ }^{29}$ where Forrester enquires into the grounds for believing that a leper he encounters in India is of equal worth to himself, and offers important thinking on the nature of equality. To understand the characteristics of communities, I will turn to Stephen Backhouse, a member of the Archbishop's Commission. He explores this issue in "Spaces and Neighbours," his contribution to A Theology of Housing, and characterises communities as 'herds' or 'neighbourhoods.' ${ }^{30}$ I will also draw on Ken Leech's thoughts on the parish as a community expressed in The Sky is Red. He writes from the perspective of an "urban priest" and a "socialist Christian" who is attempting to be "a community-based theologian" in Whitechapel where "the Christian community exists as a minority faith in the midst of a large Muslim population" surrounded by "the uncommitted and the unattached." Written in 1997, his reflections on how the Church as a community can "live and testify with integrity" whilst "respecting diversity of belief and lifestyle" remain a significant challenge. ${ }^{31}$ Throughout, I will set the views expressed in the context of those encountered by Nixon in his interviews. He explores more directly than Gibbs and Courtenay the experience of his interviewees with the church - both the Church of England and other denominations. I will also draw on Kimberly Bracken Long's paper on "how the presence of homeless Christians affects a worshipping congregation." 32 Although she writes in a US setting, the observations that she makes on the challenges and the impact of their presence are very valid in the context of a Church of England parish. To gain a gospel perspective on the role of people on the margins in the Church community, I will turn to Jane Kopas' article "Outsiders in the Gospels: Marginality as a Source of Knowledge." She shows how "the gospels are populated with a cast of marginal women and men" who "have a wisdom of their own to share." 33 It is this

${ }^{29}$ Duncan Forrester, On Human Worth (London: SCM Press, 2001).

${ }^{30}$ Stephen Backhouse, "Space and Neighbours," in Coming Home: A Theology of Housing, ed. Malcolm Brown and Graham Tomlin (London: Church House Publishing, 2020), 46-47.

${ }^{31}$ Leech, The Sky, 1-3.

${ }^{32}$ Kimberly Bracken Long, "In from the Street: When Homeless Christians Join the Worshipping Assembly," Journal for Preachers (2008), 31.

${ }^{33}$ Kopas, "Outsiders," 1. 
wisdom that I am seeking amongst women and men who have been marginalised through homelessness today.

\section{Summary}

This is a vibrant area and much significant new reflection on the issue of homelessness, the relationship between the church and the marginalised and the theology of housing is continually appearing. Coming Home, Fratelli Tutti and A Theology of Housing all emerged as I worked. These and the other sources that I draw on are thoughtful contributions that in many cases reflect a great depth of experience of working with people who are homeless and marginalised through their poverty. What I will seek to do in the discussion that follows is to put them into the context of insights from individuals with lived, and in most cases current, experience of homelessness. I will show that their observations are equally thoughtful, demonstrating that people who are marginalised need only to be given an opportunity to contribute meaningfully to the Church family.

\section{The Voices of People Who Are Homeless}

$\underline{\text { Introduction }}$

In this section, I will put the spotlight on the subject of my research question, people who are homeless. I will start by exploring who they are and how they come to be in such a precarious position. I will ask if these people think theologically, and, through published interviews, I will seek to uncover what forms this thinking takes. I will also look at a sermon by a Church of England clergywoman with lived experience of homelessness. I will conclude that they do think theologically, and that their perspectives have a wider relevance beyond their specific situation in life.

\section{Who Am I Talking About?}

My research question centres on people who are homeless. As Chamberlain and Mackenzie note, establishing who these people are is a contentious issue about which "there is little agreement

in recent academic literature." 34 For this dissertation, I will adopt what they characterise as a "conservative" approach: people without any form of shelter and people who are in emergency accommodation. ${ }^{35}$ Whilst this has the virtue of establishing a clear and relatively unambiguous boundary to my consideration, it has significant limitations too. Chamberlain and Mackenzie note that there is a distinction between a shelter and a home. Whilst, for example, a tent can provide

\footnotetext{
${ }^{34}$ Chamberlain and Mackenzie, "Understanding," 274.

${ }^{35} \mathrm{Id}, 275$.
} 
shelter, it would not be considered a home in England today. ${ }^{36}$ How are such interpretations arrived at? Chamberlain and Mackenzie point to the role of social norms. The "notion of a 'home' indicates certain minimal housing conditions that a particular community believes people have the right to expect." 37 This makes homelessness "a socially constructed cultural concept that only makes sense in a particular community at a given historical period." ${ }^{38}$ In England, for example, most of the population live in self-contained houses which they own (the majority) or rent. ${ }^{39}$ It follows that this establishes the prevailing norm: that an independent person or couple can expect "at least a room to sleep in, a room to live in, kitchen and bathroom facilities of their own and security of tenure" which is the minimum that people achieve in the rented market even if it is "significantly below the culturally desired option of owner occupation." ${ }^{40}$ Chamberlain and Mackenzie contrast this view with what they term a "radical" conception of homelessness, which gives "priority to the perceptions of the actors" about "the adequacy of their accommodation as they perceive it."41 Whilst these perceptions may differ from the prevailing norm, this norm still provides "the point of reference for this dissent." 42 Nixon points out that because home is regarded as "a category to define normality," then "its opposite - homelessness, becomes a term of abuse for those who fail to conform." 43 These considerations will become significant when I consider how a parish church congregation that largely conforms to the norm responds to individuals who do not.

How do people become homeless? Nixon found that his interviewees arrived at a crisis point of being without a home or having to spend a night without a roof normally because of a health related or relationship problem, issues around childhood, the death of family members, sexuality or crime. The crisis has results such as self-harm, suicide attempts or substance abuse, which can become causes in themselves creating a circular effect. Nixon concludes that "homelessness is the public presenting issue for a number of other serious concerns which have otherwise remained largely within the private domain." 44 A point that I shall return to is that these concerns are not exclusive to people who are homeless. For example, Nixon speaks with Caroline,

${ }^{36} \mathrm{Id}, 278$.

${ }^{37} \mathrm{Id}, 277$.

${ }^{38} \mathrm{Id}, 290$.

${ }^{39}$ Ministry of Housing, Communities and Local Government, English Housing Survey, 2018-19, accessed 24 November 2020.

${ }^{40}$ Chamberlain and Mackenzie, "Understanding," 290.

${ }^{41} \mathrm{Id}, 275$.

${ }^{42}$ Id, 290.

${ }^{43}$ Nixon, Stories, 59.

${ }^{44}$ Id, 82-3. 
Charlie and Danni who struggle with alcoholism and could equally be categorised as recovering alcoholics, a category which might include other members of a parish church congregation, including some who are concealing this issue. ${ }^{45}$

\section{Spirituality Amongst People who are Homeless}

Do individuals with overwhelming physical needs think of anything other than the immediate need to survive? Can they be said to think theologically? What, indeed, does theological thinking mean? Gibbs warns against imagining that "when you think about faith or religious belief that people are committed to a particular church or religion, when the reality is that they are searching for meaning and this is where you would look for it." ${ }^{\text {"6 }}$ The interviews that he, Nixon and Courtenay present provide considerable evidence of such searching. The diversity of views Nixon encounters "give a clear sense of the significance of spirituality in the lives of his subjects." Whilst some had almost nothing to say, for others "talking about God was seemed part of their natural discourse." ${ }^{47}$ Nixon was struck that many participants are trying "to express complex ideas without many of the tools to do so." These ideas can be explicitly or implicitly Christian or couched in Christian language. Others try to "describe their own ideas." 48

Despite this interest, only two of the eleven currently attend a church, and most see the institution as either irrelevant or threatening. Although Caroline has a Christian background, attended Mass as a child and calls herself a Roman Catholic, she is agnostic about God and sees almost no connection between her life and the Church. ${ }^{49}$ Caroline recognises that churches might be there to help people like her, she "does not see in reality how they could have done so." 50 The support she most values came from her key worker, to whom she told "everything from when I was young, from the age of six upwards." ${ }^{51}$ Similarly, Julie grew up in a children's home run by nuns and attended a Church of England school, but is now critical of the Church and does not see it as important. She only goes at Christmas, but is keen to share her faith with those that she meets. She says that "I try to pass on my own messages and that's all the disciples did. They stayed down there with the people - sometimes you can't reach the people at the top." ${ }^{52}$ Charlie is also

\footnotetext{
${ }^{45} \mathrm{Id}, 67-68,83-4,71-2$.

${ }^{46}$ Gibbs, Staying in, 173-4.

${ }^{47}$ Nixon, Stories, 111.

${ }^{48} \mathrm{Id}, 119$.

${ }^{49} \mathrm{Id}, 68$.

${ }^{50} \mathrm{Id}, 114$.

${ }^{51} \mathrm{Id}, 102$.

${ }^{52} \mathrm{Id}, 117$.
} 
concerned about the power relationships within the Church: "Everyone should be equal with the Church. They're not, are they?" ${ }^{53}$ He resented going to a church for a free meal and being compelled to repeat a Hail Mary first. ${ }^{54}$ Geoff's view is coloured by his Catholic school, and he resents "religion being rammed down my throat." 55 There are more positive views though. Tim likes his Baptist Church because it "takes an interest in him whilst respecting his lifestyle." 56 The difference seems to be listening. Nixon believes that "careful listening honours and validates" the accounts of vulnerable lives that he hears. ${ }^{57}$ That is why his interviewees value their time with him, Caroline values her project worker and Tim values his church. The suspicion with which Charlie, Geoff and Fran view the church follow experiences of being preached at. This has made them reluctant to engage with it, destroying any opportunity for dialogue. The fact that Tim's church does not try to "cure" him of homelessness or assume that he wants to change his lifestyle is important, and something I will return to later.

\section{Edward, Asif and Mary}

By contrast with Nixon, Courtenay does not ask directly about religion and discloses no views of her own. Only one interviewee, Edward, discusses it. Courtenay encountered him living in a bright red tent, a shelter rather than a home according to English social norms. He has lived on the streets for 15 years and has adopted a "kind of Buddhist philosophy that everything is transient and changes." 58 This perspective has helped him overcome mental illness and physical discomfort, and enabled him to find positives as well as negatives in his insecure, uncomfortable and dangerous lifestyle. He fills his time with museums and counting eels for a wildlife charity. He would like to improve his position, but, like Tim, he "wouldn't choose a different life" because he has "a measure of freedom." 59

Gibbs identifies other ways in which people who are homeless think about spirituality in his interviews. I will focus on two of the five interviews that he presents, Asif and Mary. Asif is a 40-year-old Somali refugee of Islamic faith who has been granted asylum following a horrific experience of ethnic conflict in his country of birth, Somalia, including the murder of family

\footnotetext{
${ }^{53}$ Id.

${ }^{54}$ Id.

${ }^{55}$ Id.

${ }^{56} \mathrm{Id}, 79$.

${ }^{57}$ Id, 117.

${ }^{58}$ Courtenay, Four Feet Under, 115.

${ }^{59} \mathrm{Id}, 119$.
} 
members. The appalling events of his life can bring him to despair at times, but at other times his faith breaks through to give hope:

In places Asif expresses feelings of total hopelessness and yet, just like sunlight on a cloudy day, there were occasional brief rays of hope that would try and break through. As previously expressed, when imprisoned following the murder of his brother, he believed that he would not leave the prison alive. His family was as far as he knew dead, and yet hope came into the narrative when he expresses that "God saved him." 60

This faith in God's deliverance leads him to hope for the future. Gibbs finds that "his hope is that he can be washed clean, which is very much a symbolic act both in the Islamic and Christian faith." ${ }^{61}$ Gibbs believes that Asif needs to "come to terms with the shame, guilt and anger in an environment of trust." The host organisation "should be able to provide this and meet his need to give answers to some of the questions that persist and his need for forgiveness." ${ }^{62}$ However, Gibbs notes Asif's disturbance is exceptionally severe, and without adequate support and experience staff can "easily become overwhelmed and paralysed, feeling totally inadequate and becoming ineffective." 63

Mary, a Druid, is 25 . Her childhood was characterised by a messy divorce and a difficult relationship with her controlling father, who cut off contact with her mother and eventually threw her out of the family home at 16. An aspiring writer, she "wants to leave something behind - have her work published to leave something immortal," which is connected to her "belief that she is going to die early." ${ }^{64}$ Mary fears that has inherited the genetic disease that brought about the untimely death of her mother. Gibbs suggests that "the host organisation has failed her" by not engaging with her "questions about life and mortality, questions that of all organisations the host organisation should be able to contain and give space to consider." ${ }^{65}$ All she encountered was "a project worker preaching to her about Jesus." By contrast, Gibbs concludes that "the interview is something of what Mary has been looking for, somebody to begin to get to know her, to understand

\footnotetext{
${ }^{60}$ Gibbs, Staying in, 158.

${ }^{61} \mathrm{Id}, 159$.

${ }^{62}$ Gibbs, Staying in, 154. The host organisation is the Salvation Army.

${ }^{63} \mathrm{Id}, 156$.

${ }^{64} \mathrm{Id}, 171$.

${ }^{65} \mathrm{Id}, 173$.
} 
her, and begin to help her work through her past, present and future." 66 Although the preaching on salvation left her cold, Mary is interested in "hope, meaning, belief and faith - revelation." 67

\section{A Sermon on Hope}

Finding hope is also central to the sermon by Bosede Owa. Firstly, she echoes Nixon's theme of the power of the story when she emphasises for her Church community the importance of being connected with other Christians and to listen to each other's stories. As she puts it, sharing stories means hearing what other Christians are going through and how they are overcoming it. ${ }^{68}$ In support, she highlights the importance Old Testament Israelites attached to recording their stories and accounts of how they overcame their enemies. ${ }^{69}$ She alludes to, rather than recounts, her own story when she says "I know when you are going through a lot it is not easy, trust me I have been there." ${ }^{70}$ Drawing on her biography, she turns to a second theme: the importance of remaining hopeful even in an apparently hopeless situation. She warns that the greatest danger facing the church today, in the context of COVID, is buying into the mentality of hopelessness and impossibility that weakens true faith. ${ }^{71}$ Remaining hopeful is a continuous challenge for people experiencing homelessness. Gibbs finds that all those he interviewed retained "some hope and optimism about their future life away from homelessness." 72 For Owa this hope has been fulfilled. For Asif and Mary, it has not but they need to remain hopeful.

\section{$\underline{\text { Conclusion }}$}

Drawing this together, what can I conclude having heard the voices of Edward, Asif, Mary, and Nixon's interlocutors? First, that listening to the homeless is important. Caroline's key worker and Tim's church succeeded because they listened. Mary's project worker failed because she didn't. Second is the importance of storytelling. The stories that people who are homeless tell and the opinions that they voice have a general relevance. Many of the problems they face are shared by others. Owa finds hope in an apparently hopeless situation, but there are other ways too. For example, Julie and Charlie draw attention to the power relationships that operate within a Church.

\footnotetext{
${ }^{66} \mathrm{Id}, 176$.

${ }^{67} \mathrm{Id}, 176$.

${ }^{68}$ Owa, "Summer Psalms," 14:04.

${ }^{69} \mathrm{Id}, 14: 53$ and 15:04.

${ }^{70} \mathrm{Id}, 5: 33$.

${ }^{71}$ Owa, "Summer Psalms," 6:50.

72 Gibbs, Staying In, 199.
} 
Listening is important not just because it helps them, but also because their views can help us. Is the Church willing to hear them?

\section{The Church of England and People Who Are Homeless}

\section{$\underline{\text { Introduction }}$}

This brings me to examine the direct object in my research question: the parish church. I start with current social action within the Church of England, and look at the $2020 \mathrm{CUF} / \mathrm{Theos}$ report, Growing Good. I will uncover that although the Church espouses a mission to help people who are poor, their voice is absent from the report. I will then explore the attitude of congregations and the clergy to the poor of the parish, and specifically to those who are homeless, and discover that congregations can be judgmental. I will look at the materials offered to support Homeless Sunday and show that they reinforce rather than challenge those attitudes. Finally, I will turn to Coming Home and examine its vision for the relationship between parish churches and people who are homeless. I will conclude that congregational attitudes are a barrier and a transformation is needed, but that this transformation can only occur if people who are poor, including those who are homeless, can overcome their marginalization and make their voices fully heard.

\section{Church of England Work with People Who Are Homeless}

Church in Action highlights that parish churches are undertaking a significant level of work to support people who are homeless. No fewer than $71 \%$ of churches are doing something, from organised activities and informal help to running a night shelter $(6 \%) .{ }^{73}$ Is the Church a positive influence, though? In 1997, Leech was troubled that although "there is a good deal of work 'among' poor and despised people and groups" much of it is very patronising and dehumanising." 74 This comes about partly because "most Church strategies are aimed at maintaining established structures, particularly those which are 'successful.' But the Church is 'successful' in the main among the comfortable, conventional, affluent and secure."75

Are things any better now? To address that question, I will apply the ARCS framework of theology in four voices to the most recent survey of Church social action: Growing Good. The report gives limited access to the operant theology of Church work with people who are homeless, but I will look closely at the other three voices and how they interact. To what extent does the

\footnotetext{
${ }^{73}$ Sefton and Buckingham, Church in Action: A National Survey, 12 and 15.

74 Leech, The Sky, 248.

${ }^{75} \mathrm{Id}, 227$.
} 
espoused theology expressed in the body of the report align with that which emerges in the recommendations for action? What authorities does it regard as normative, and what, if any, formal theology does it draw on? Do these authorities include the voice of the beneficiaries of social action, at either of the levels highlighted above? The report does allude to the four voices framework, but tellingly, it regards only the espoused and operant voices as relevant. ${ }^{76}$ Formal theology is almost entirely absent. Growing Good mentions Peter Berger's plausibility structures in considering that if the church is seen to be doing good in the shape of social action, this increases "the plausibility [in the public eye] that the belief systems behind it are also good."77 Beyond this, there is no reflection on reasons other than creating growth as to why the Church might be called to serve people who are poor.

The normative theology emerges most clearly in the chapters on definition and context. Here, Growing Good relies heavily on the authority of the Church of England. For example, it states that "the significance of our three core themes - church growth, social action and discipleship - lay in the fact that they are at the centre of the Church of England's mission and self-understanding. They are priorities at a local and national level."78

In discussing what church growth might mean, it looks at how "the Church of England measures and defines growth." 79 Looking at discipleship, Growing Good cites the Church of England's Five Marks of Mission pointing to the call to "to teach, baptise and nurture new believers." ${ }^{\prime 80}$ However, when it comes to defining social action, it does not mention the call in the Five Marks "to transform unjust structures of society." 81 Instead, it defines social action as "the collective activity of congregations to establish means of support or effect social change in ways consistent with Christian social witness," language that is significantly weaker and less direct. ${ }^{82}$ It is worth noting that both definitions are centred on doing things for people, and ignore the need to listen at either the first or the second level.

What of the espoused theology of Growing Good? The introduction highlights that "congregations and church leaders should be equipped to think about social action, discipleship

\footnotetext{
${ }^{76}$ Rich, Growing Good, 61.

${ }^{77} \mathrm{Id}, 125$.

${ }^{78}$ Rich, Growing Good, 41.

${ }^{79}$ Rich, Growing Good, 29-30.

${ }^{80} \mathrm{Id}$, 30, citing Mission Theology Advisory Group (MTAG), "The Five Marks Of Mission," at 3.

${ }^{81}$ MTAG, "Five Marks," 3.

82 Rich, Growing Good, 37.
} 
and church growth in an integrated way rather than as three independent concepts. ${ }^{83}$ It appears to recognise that "Church growth is not the primary goal of social action." 84 However, elsewhere, it contradicts this and presents social action as "a route to church growth" which is defined as "primarily numerical, but in broader terms than attendance." ${ }^{\circ 5}$ Where is this growth to come from? It sees drawing in volunteers from the wider community as a key opportunity, saying that "participation in social action can offer a valuable and significant route into faith and discipleship for people who weren't previously part of the church community." 86 This thinking is reflected in the recommendations. Five recommendations focus on drawing in volunteers from the wider community, on changing the metrics for growth to reflect this new form of participation, and on resourcing this activity. Although it does call on congregations to reflect on the culture of their social action, this is not its focus. ${ }^{87}$

Nixon worries that Church mission work is "often constructed around church attendance and financial survival." 88 This shortcoming is apparent here. Although Growing Good espouses the view that "social action can be a route to church growth in both numerical and spiritual terms" its focus is on the numerical. ${ }^{89}$ The Church as a community needs a vocation beyond survival. Growing Good does not articulate one. It notes that "the manner in which social action is approached is what makes it conducive to congregational growth," adding that "without an intentional culture of hospitality, social action in any form can remain purely transactional rather than transformative for the entire church community." 90 Nixon's interviews show that people who are homeless have clear views on both the vocation of the Church and the culture within it, but their voices are absent from Growing Good. There is a series of studies on people who have benefitted from help from the Church, but these highlight the role of the Church and ignore the opinions of the beneficiaries. Unless those voices come through, the "culture of hospitality" that will make social action "transformative" is unlikely to emerge. Such a culture needs to start from a welcoming rather than a judgmental attitude. What is the attitude amongst Church congregations to people who are poor and specifically those who are homeless?

\footnotetext{
${ }^{83} \mathrm{Id}, 14$.

${ }^{84} \mathrm{Id}, 144$.

${ }^{85} \mathrm{Id}, 12,30$.

${ }^{86} \mathrm{Id}, 57$.

${ }^{87} \mathrm{Id}, 151-154$.

${ }^{88}$ Nixon, Stories, 64.

${ }^{89}$ Rich, Growing Good, 12.

${ }^{90} \mathrm{Id}, 86,57$.
} 


\section{Congregational Attitudes to People Who Are Poor}

A 2020 CUF survey found that $96 \%$ of respondents agreed that "as a Christian I believe God calls me to practically respond to poverty and injustice." ${ }^{91}$ Despite this, and the considerable work highlighted above, Bias to the Poor uncovers the fact that "churchgoers attitudes to poverty are little different to those of non-churchgoers." In both groups more attributed poverty to laziness and lack of willpower (23\%/27\% respectively) than to social injustice $(22 \% / 20 \%)$. Others just regard it as an inevitable part of modern life $(38 \% / 38 \%)$ or blamed poverty on bad luck $(12 \% / 10 \%) .{ }^{92}$ Although churchgoers believe they have a calling to respond to "poverty and injustice" most do not regard people who are poor as victims of injustice. Many regard poverty as a normal feature of life and a substantial minority believe it is the fault of those experiencing it. These attitudes will inevitably affect the willingness of Church members to listen to individuals such as those interviewed by Nixon, Gibbs and Courtenay, especially at the second level when they critique the lives and values of more prosperous members of the congregation. Bias to the Poor concludes that "if, as we believe, tackling poverty is at the heart of the gospel message, then there is a clear need for churches to do more to raise awareness and understanding of these issues among their congregations." 93

What is the Church doing to address this need? Homeless Sunday has been part of the Church calendar for over a quarter of a century. Yet Bias to the Poor finds that in this time attitudes to people who are poor such as people who are homeless have hardened. ${ }^{94}$ Why is this? What messages are conveyed during this service?

Homeless Sunday - shaping the values of congregations?

In October 2020, the main Homeless Sunday sermon for Church of England's parishes to use was presented by Wickham. He starts by remarking that Homeless Sunday is an occasion for "soul searching about the way in which we support the vulnerable." 95 This wording puts the focus firmly on doing things for these people rather than understanding how they get into this situation or hearing what they might have to say to us. His references to people who are homeless as $2020,2$.

${ }^{91}$ Church Urban Fund, "Key Findings from and commentary on the CUF Survey," accessed 10 December

${ }^{92}$ CUF, "Bias to the Poor," 2.

${ }^{93} \mathrm{Id}, 4$.

${ }^{94}$ CUF, "Bias to the Poor," 4.

${ }^{95}$ Rob Wickham, "Homeless Sunday Sermon," Housing Justice, accessed 10 December 2020, 0:36. 
"broken" and "marginalised" portrays them as needy rather than able to give anything. ${ }^{96} \mathrm{He}$ positions relationships with people who are homeless as a one-way channel for advice, implying that volunteers will give but have no need to receive in return. ${ }^{97}$

The associated video opens with an unnamed young man, but he gets just one minute in a four-minute presentation, half of which is given to expressions of gratitude for the help received from a Housing Justice volunteer. He relates that he gave up his flat and his job because he was missing home too much. The uncharitable could view him as someone passive, who is unable to help himself or offer anything and perhaps could get a job if he wanted to. Rather than providing more context, the remaining 3 minutes are devoted to an appeal by Wickham. ${ }^{98}$ However the London version of the video appends an interview with a crucial difference. Aiden, a Housing Justice volunteer host, reveals how he has learned from the resilience shown by Ephrem, his refugee guest, at a really difficult time in his life. ${ }^{99}$ The homeless person had something to give to the volunteer. This is the only evidence of listening at the second level in the entire service. This aside, the main Homeless Sunday materials reinforce rather than challenge negative perceptions of people who are homeless, and do not consider how people end up in that position. The materials were posted over a year after Welby announced his Commission yet fail to allude to the structural issues discussed in the publicity around the report or indeed in Welby's chapter on Housing in Reimagining Britain. ${ }^{100}$ The problem is that Wickham and Housing Justice are not disinterested. The individuals that they present are in their care and they are addressing the community that provides the funding and practical help needed to deliver that care. These considerations have skewed their approach towards highlighting the impact of the charity and downplaying the agency and the voice of the recipients.

By contrast, Coming Home is uncompromising about the structural causes of the issues it identifies, including homelessness, stating that "the housing crisis is neither accidental, nor inevitable." ${ }^{101}$ For this reason it sees a need for parishes to shift their activity "away from crisis interventions towards focusing on the prevention of homelessness and housing insecurity." ${ }^{102}$ It

\footnotetext{
${ }^{96}$ Id, $3: 36$.

${ }^{97} \mathrm{Id}, 6: 40$.

${ }^{98}$ Housing Justice, "Homeless Sunday Video (National)," YouTube Video, accessed 10 December 2020.

${ }^{99} \mathrm{Id}, 3: 38$.

${ }^{100}$ Justin Welby, Reimagining Britain: Foundations for Hope (London: Bloomsury, 2018), 127-148.

${ }^{101}$ Archbishop's Commission, Coming Home, 5.

102 Id, 61.
} 
clearly recognises the need to listen to the voice "of those directly affected by the housing crisis." These voices appear in the report, which includes multiple highlighted passages with extended direct quotations presenting housing problems that individuals have experienced. It acknowledges that in most cases these problems were unresolved at the time of publication. Yet, the biographies of the Commissioners show that none has lived experience of homelessness or even poor housing. ${ }^{103}$ As a result, although there is evidence of listening at the first level, where people who are homeless discuss their plight, there is none of the second where the people affected critique the values and lives of the Church and its congregations.

\section{Summary}

We've seen how attitudes to social justice within the Church reflect those in the world. If, as Growing Good suggests, an "intentional culture of hospitality" is to form then those attitudes themselves need to be transformed. Growing Good recommends that the connection between discipleship and social action is explicitly included in sermons and other Church teachings with additional resources provided for leaders. ${ }^{104}$ Coming Home advocates that clergy and lay activists "are offered training on how to engage on housing matters." 105 However, if Wickham, with his background, can miss the mark, this is unlikely to be sufficient. Only if the individuals affected, people who are homeless themselves, are given a voice can the Church be transformed. What needs to change within the Church before these voices can be fully heard?

\section{The Theologian Who Is Homeless}

\section{$\underline{\text { Introduction }}$}

Faithful Cities highlights the distinction between the essentially passive tolerance of diversity and the more proactive biblical practice of hospitality. ${ }^{106}$ It points out that "tolerance is the response of the powerful to the less powerful" but that hospitality "can require a changing of one's own life and understanding in the process." ${ }^{107}$ In this section I will argue that to be transformed by the insights of people who are homeless, the parish church needs to move from the attitude of tolerance reflected in Bias to the Poor to one of hospitality. I will begin by defining

${ }^{103} \mathrm{Id}, 102-6$.

${ }^{104}$ Rich, Growing Good, 152/3.

${ }^{105}$ Archbishop's Commission, Coming Home, 98.

${ }^{106}$ Commission on Urban Life and Faith, Faithful Cities: A Call for Celebration, Vision and Justice, (London: Church House Publishing 2006), 23 3.42.

${ }^{107}$ CULF, Faithful Cities, 233.43 
spiritual growth drawing on Dorr. I will then look at one of the key concepts that Dorr highlights, that of solidarity. Catholic Social Teaching and Liberation Theology both stress that solidarity implies mutual dialogue. To uncover what such a dialogue might reveal, I will consider what the interviews with people who are homeless have to say about the importance and value of a home and set this alongside views expressed by academic theologians and church leaders. I will show that there is a striking overlap, validating the maturity of the reflections of people who are homeless. I will conclude that being prepared to listen and be transformed by those reflections requires an attitude of respect towards them.

\section{What Is Spiritual Growth?}

What is meant by spirituality, whose growth is the indirect object of my research question? In Integrated Spirituality, Dorr bases his response on Micah 6:8: "This is what Yahweh asks of you, only this: that you act justly, that you love tenderly, that you walk humbly before God."108

Dorr points out that the three dimensions of spirituality presented here can be grouped under overlapping headings. To "act justly" can be regarded as referring to the public aspects of spirituality such as structural justice, to "love tenderly" can refer to the interpersonal aspects and to "walk humbly" could refer to personal aspects. ${ }^{109}$ In exploring these areas, Dorr draws out some important themes. Acting justly encompasses a "sense of solidarity with other people [which] is crucial to a genuine morality." 110 For Dorr interpersonal respect is central to "loving tenderly." He considers power, and examines how "human relationships of all kinds from the international level right down to the family level involve the use or abuse of power." ${ }^{111}$ Dorr sees transparency and openness as fundamental to building a community. This is central to the personal aspect of his framework for viewing spiritual development: "walking humbly." ${ }^{112}$ I will return to interpersonal respect and building community later, but here I consider the meaning and importance of solidarity.

\section{$\underline{\text { Solidarity }}$}

Solidarity implies a willingness to listen fully to people who are homeless and to be transformed by them. This is an important point. As Faithful Cities points out, it is "not enough to simply develop a theology for the poor but we have to make space for the development of a

\footnotetext{
108 Dorr, Integral Spirituality, 1. Dorr uses The Jerusalem Bible.

109 Id, 1-3.

${ }^{110} \mathrm{Id}, 12$.

${ }^{111} \mathrm{Id}, 40$.

$112 \mathrm{Id}, 3$.
} 
theology of and from those experiencing poverty." 113 This means that "theology is not just academics talking about God - it is also the 'people's work." Specifically, it argues that "the voices of resilience, service, grace and hope that have emerged from such situations deserve greater attention." 114 Edward points out that people who are homeless live outside "the norms, the stresses of society" and likes to think that he has emancipated himself. ${ }^{115}$ This gives him the ability to critique its values from the outside looking in. Why is it important that his voice is heard alongside those of academic theologians, church leaders and "successful" (in a material sense) members of a church congregation?

In Fratelli Tutti, Pope Francis draws attention to the need for dialogue right across the human family. He points out that lack of dialogue means that people "are concerned not for the common good, but for the benefits of power or, at best, for ways to impose their own ideas." $116 \mathrm{He}$ characterises authentic dialogue as involving "the ability to respect the other's point of view and to admit that it may include legitimate convictions and concerns. Based on their identity and experience, others have a contribution to make, and it is desirable that they should articulate their positions for the sake of a more fruitful public debate."117

Liberation Theology goes further. Gutierrez says there can be no "authentic and complete" liberation unless it "stems from the values proper to these people." 118 As Nixon points out, this liberation is bi-directional. The Church and its congregations need to be "set free from their own oppressive instincts" by becoming "one with the homeless who alone are able to set them free." 119 What Is Homelessness?

In what sense can a Church congregation, who by and large have a place that they regard as home, become one with individuals who don't? Recall how Chamberlain and Mackenzie showed that homelessness is a concept that is defined by the prevailing norms and values in a specific community at a specific time. ${ }^{120}$ These norms and values have been subject to challenge

\footnotetext{
${ }^{113}$ CULF, Faithful Cities, 152.59.

${ }^{114}$ CULF, Faithful Cities, 142.55.

115 Courtenay, Four Feet Under, 113.

${ }^{116}$ Francis, Fratelli, paragraph 202.

${ }^{117} \mathrm{Id}$, paragraph 203.

118 Gutierrez, A Theology, 91.

${ }^{119}$ Nixon, Stories, 13.

${ }^{120}$ Chamberlain and Mackenzie, "Understanding," 290.
} 
by academic theologians, but are also questioned within the interviews undertaken by Nixon, Courtenay and Gibbs. How do these challenges compare?

Button describes homelessness "as a lack of belonging" and thus a "liminal state." He adds "when a person becomes trapped by homelessness, when they are entrenched rough sleepers, then the liminal has stalled." He concludes that "to be homeless is to have experienced sufficient loss of extended identity attributes to allow the superimposition of an alternative or external identity which leads to the person no longer feeling that they belong anywhere." 121

Edward articulates a similar view based on his experience of 15 years on the streets of London. He tells Courtenay that whilst his Buddhist spirituality helps him transcend materialism and not worry that he is missing out, he notes that a lot of depression amongst people who are homeless is "triggered by the fact that they haven't got anywhere to go back to." 122 He regrets that he cannot have a wife or family in his current situation: "if I want to have a family I have to have a house or a flat to live in." ${ }^{123}$ Edward does have friends but he has nowhere to offer them hospitality. He has nowhere to store the possessions he does have, and cannot put pictures up on a wall. ${ }^{124}$ Nixon encounters a similar "tension between the desire for freedom and the equally strongly held wish to belong and feel at home" in his interviews with Charlie and Tim. ${ }^{125}$

To what extent does everyone who has "a place to go back to" actually have that sense of belonging? Watching commuters emerge from London Bridge at 6am, Edward asks "what are they doing? A lot of those people aren't happy." ${ }^{126}$ His impression is confirmed by the Office for National Statistics which found that the effect on personal well-being of long commutes is not compensated for by material gains. ${ }^{127}$ Why are they not happy? They must have left home at 5am or earlier. After a full day at work, they will not return until 7-8pm. For many this will be a daily routine. They can do little more than eat and sleep at home during the week. Are they not, like Edward, trapped in a liminal state, impoverished by their itinerant lifestyle? Edward sees "being homeless isn't so much a barrier as a way to free myself from all the things that are going to tie

${ }^{121}$ Button, "Where do I," 157.

${ }^{122}$ Courtenay, Four Feet Under, 119.

${ }^{123} \mathrm{Id}, 117$.

${ }^{124} \mathrm{Id}, 115-6$.

${ }^{125}$ Nixon, Stories, 97.

${ }^{126}$ Courtenay, Four Feet Under, 115.

${ }^{127}$ Office for National Statistics, "Commuting and Personal Well-being, 2014," accessed 10 December 2020, $1,15$. 
me down - things like council tax, rent and things that I don't need." ${ }^{128}$ Similarly, Charlie explains how "instead of living in a house with a regular job and a mortgage...you just have yourself to worry about." 129

Edward and Charlie challenge the values that tie these commuters to their daily journey. Justin Welby and the Commissioners who contributed to Coming Home express very similar concerns from a formal theological perspective. In Reimagining Britain, Welby is troubled by the nation's "addiction to increasing the proportion of home ownership, and to making money on houses as investments [which] has become a practice that demonstrates the shallowness of our underlying values." ${ }^{130}$ In A Theology of Housing, Graham Tomlin adds that the market-driven approach to housing "so often expresses the idea that a home is a place to exclude people, or a reward for success, or an asset to shield against the winds of change, something to put our trust, savings and wealth into." ${ }^{131}$ In the same volume, Harris and Sweetland point out that, "For some, houses are not homes but assets to accumulate, while others are left without." 132 Malcolm Brown points out that a house ought to be "the vehicle through which people become located within specific places and communities." 133 The Church implicitly recognises this by providing its clergy with a home within the parish. Yet the lengthy daily journey undertaken by the commuters Edward sees emerging from London Bridge will impact their connection with those communities, and indeed with the families who share their home.

Summary

Welby, Tomlin and Brown critique society's values as formal theologians and express their concerns in a widely circulated and promoted report. Edward, Charlie and Tim do so from their experience of life on the streets, but their views are not given the same attention. Yet, coming from very different starting points, they say similar things about the meaning of home, both the real value that it has and how it can restrict us. It is important not only that individual and societal values are challenged but also who is issuing the challenge. Following Paolo Friere, Nixon says,

${ }^{128}$ Courtenay, Four Feet Under, 114.

${ }^{129}$ Nixon, Stories, 97.

${ }^{130}$ Welby, Reimagining Britain: Foundations for Hope, 138.

131 Tomlin, "A Theology of Housing," 2.

${ }^{132}$ Nicola Harris and Jez Sweetland, "Community, Hospitality and Space-making," in Coming Home: A Theology of Housing, ed. Malcolm Brown and Graham Tomlin (London: Church House Publishing, 2020), 165.

${ }^{133}$ Malcolm Brown, "Housing, Church and Community - and Christian Theology," in Coming Home: A Theology of Housing, ed. Malcolm Brown and Graham Tomlin (London: Church House Publishing, 2020), 53. 
"it is the oppressed who will restore the humanity of both themselves and the oppressor." 134 Is a member of a parish church who has a long daily commute prepared to have the values that underpin her choice challenged by someone whose homelessness puts him outside the norms of society, such as Edward? He is an educated man (he has a degree in marine biology). ${ }^{135}$ Does he also need to make the transition that Owa underwent and conform to those norms before his views and values are taken seriously? This brings us to the second issue that Dorr raises, that of interpersonal respect. To understand why the voices of people who are homeless are not heard, I will consider the stigmatisation of people who are homeless, and the impact that this has on their relationship with the Church.

\section{Interpersonal Respect and the Importance of Narrative Theology}

\section{$\underline{\text { Introduction }}$}

Nixon challenges the Church to "balance negative images of homeless people with a recognition of their strengths." ${ }^{136} \mathrm{He}$ is paralleling Dorr's call for interpersonal respect which for him is central to "loving tenderly." 137 Yet as Button points out "the image of the homeless person is often generalised with a particular identity of 'homelessness' having its ... own assumed characteristics." 138 Following Charturvedi, Button notes that "when one identity attribute is heavily stigmatised it can become dominant." 139 How can this stigmatisation be overcome in the context of a Church community? I will start by showing how one-way acts of giving reinforce the powerlessness of the recipient and can lead to unbalanced relationships with volunteers. I will show that this issue is exacerbated by the stories told by homeless charities such as Housing Justice. I will then consider the power of narrative theology, and reflect on why the stories that people who are homeless tell of themselves are different in character from those that are told about them. I will show that these stories break down the categorisation and negative images that lead to stigmatisation. I will conclude that storytelling can be a reciprocal activity that can rebalance relationships providing a platform on which to build a community that includes them.

${ }^{134}$ Nixon, Stories, 12.

${ }^{135}$ Courtenay, Four Feet Under, 114.

${ }^{136}$ Nixon, Stories, 182.

${ }^{137}$ Dorr, Integral Spirituality, 3.

${ }^{138}$ Button, "Where do I," 155.

${ }^{139}$ Id, citing Surahbi Charturvedi, "Homelessness, Identity and the Therapeutic Space," BACP Children and Young People (September 2014), 26. 


\section{The Burden of Stigma}

Gibbs shows how the authorities keep Asif alive "but do not allow him to participate, thereby forcing him into being an outsider." ${ }^{140}$ Does Church charitable work with people who are homeless similarly exclude them while addressing their material need? As Button says: "the enacted power imbalance of charity given can reinforce the lack of belonging and the embodiment of the homeless identity." ${ }^{141}$ Dorr points out that "we cannot build community simply by doing things for people or giving them things." 142

Button warns that "seeing service as a one-way gift is ultimately destructive for both the giver and the receiver." ${ }^{143}$ Growing Good illustrates why with this telling observation:

In several case studies, we encountered congregation members wrestling with the sadness of an individual they had invested time and energy into having reoffended or fallen back into addiction. Sometimes they questioned whether the faith and transformation they had celebrated had been genuine, and whether it had been worth it only to experience the ensuing disappointment and grief. ${ }^{144}$

There are three troubling words here. The first is "invested" which implies a relationship of one-way giving rather than of mutual respect. The second is "celebrated," which implies that the exercise had a goal of achieving transformation rather than shared growth and learning. The failure of the receiving party to deliver it leaves us in the presence of "disappointment." Where does the expectation come from that time spent with an individual who is homeless should be transformational? Growing Good presents five accounts of people who are poor and or homeless in its pages. Each one of them has an upbeat "happy ending." 145 Wickham talked of how Housing Justice has "saved" and "turned around" the lives of two named individuals. ${ }^{146}$ Yet none of the interviews that Nixon, Courtenay and Gibbs present have such an ending. The disappointment, then, comes not only from the one-sided nature of the relationships, but also from the expectations created by the narratives presented by Housing Justice and reports like Growing Good. Stories have power. I will now consider stories, and the different ways in which they are told and used.

\footnotetext{
${ }^{140}$ Gibbs, Staying in, 158.

${ }^{141}$ Button, "Where do I," 158.

142 Dorr, Integral Spirituality, 69.

${ }^{143}$ Button, "Where do I," 158.

144 Rich, Growing Good, 103.

${ }^{145} \mathrm{Id}, 85,97,109,119,127$.

${ }^{146}$ Wickham, "Homeless Sunday Sermon," 3:10.
} 


\section{Narrative Theology}

Nixon follows Moltmann in saying that readers "not only want to know what an author has to say but also how he or she arrived at it." ${ }^{147}$ Owa draws our attention to the importance of stories, and expounds a perspective on hope that she drew from her "situation and biography." ${ }^{148}$ Although Moltmann recognises the need to retain objectivity in Christian theology, this needs to be set alongside "biographical subjectivity." This, as Moltmann says, is central to the concept of narrative theology, as opposed to argumentative theology. ${ }^{149}$

With this in mind, I will return to Wickham's Homeless Sunday sermon, and consider how he arrived at it. His background includes an education in academic theology, as well as extensive observation of people who are homeless over 20 years of pastoral work with them. He is not, however, drawing directly on his own life experience. There are Church of England clergy who can, like the Reverend Grace Thomas, who has experienced homelessness twice. In a video elsewhere on the Internet she, like Wickham, highlights how the Church can help by building relationships, but Thomas discloses how, at the time she was homeless, she was reluctant to turn to the church because of her fear of judgement and that it was her friends who got her through. ${ }^{150}$ Wickham mentions evictions in passing. Thomas describes having to hide from the rent collector as a single teenage mother, even though she was training to be a nurse. ${ }^{151}$ Wickham barely alludes to injustice. Thomas remembers having to return to a home from which she and her mother had fled because the only shelter available was cramped and lacking privacy. ${ }^{152}$ Where Wickham talks of lives transformed, Thomas talks of the long shadow that her experience of extreme insecurity has cast. Even now, as a married woman with a secure occupation, she is perpetually anxious about money. ${ }^{153}$ Drawing on her biography, she lays down a challenge to those who are judgemental, showing the damage that this attitude does and how misplaced it is. In this way, she gives a much clearer idea of the quality of relationship that is needed.

${ }^{147}$ Nixon, Stories, 6, citing Jurgen Moltmann, Experiences in Theology: Ways and Forms of Christian Theology (Fortress Press, 2000), pxix.

${ }_{148}$ Moltmann, Experiences in Theology, pxix.

${ }^{149}$ Id, pxix.

${ }^{150}$ Grace Thomas, "Grace's Story," YouTube Video, Joint Public Issues Team, accessed December 11 2020, $2: 55$ and $4: 21$.

${ }^{151} \mathrm{Id}, 1: 12$.

${ }^{152}$ Id, 0:26.

${ }^{153}$ Id, 1:34. 
What distinguishes Thomas' first-hand account from Wickham's second-hand reports? How is Owa's story as it appears in Growing Good different in character from her own telling of it in her sermon? ${ }^{154}$ In The Wounded Storyteller, Frank categorises stories into three types: the restitution narrative, the chaos narrative and the quest narrative. The restitution narrative "has the basic storyline, yesterday I was healthy, today I am sick, but tomorrow I'll be healthy again.”155 Often, a helper is involved providing a remedy, whose success validates the helper. The subtext is that "for every suffering there is a remedy." ${ }^{156}$ Homeless charities, such as Housing Justice, often present the stories of people who are homeless as restitution narratives, as Wickham does. The active players are the charity and its volunteers. They are "self-stories only by default." 157 Chaos narratives are the converse. Their plot imagines "life never getting better." 158 These are the stories that emerge from the interviews conducted by Nixon, Courtenay and Gibbs. They lack narrative order, a sense that one event leads to another and reveal vulnerability, futility, impotence. The quest narrative also speaks from the sufferer's perspective but "holds chaos at bay." The quest is defined by the belief that "something is to be gained through the experience." 159 It accepts the experience of homelessness and seeks to use it positively. In Growing Good, Owa's story appears as a restitution narrative, highlighting the role of her church. In her sermon, it becomes a quest, because she relates how she has learned through her experience to use her faith as a defence against hopelessness and can share this learning with others. Coming Home recognises the chaos narratives that homeless people tell and are reflected their lives, but does not seek out what they have learnt, or ask if this learning has wider relevance.

By listening to the stories of people who are homeless in their own words, we find that their experiences are ones that we all share - like finding hope in the face of seemingly insuperable difficulties. Gibbs notes that both Asif and Mary "had faced trauma and were trying to express hope for the future." ${ }^{160}$ In giving Owa a platform to speak, St John's Hoxton honoured and validated her story, and gave her to draw on it to encourage those feeling hopeless in the face of COVID. Effectively, she transcended the category of people who have been homeless to become

\footnotetext{
${ }^{154}$ Rich, Growing Good, 85.

${ }^{155}$ Frank, The Wounded Storyteller, 77.

$156 \mathrm{Id}, 80$.

$157 \mathrm{Id}, 115$.

$158 \mathrm{Id}, 97$

${ }^{159} \mathrm{Id}, 115$.

${ }^{160}$ Gibbs, Staying in, 204.
} 
a person who has felt hopeless, a much wider category embracing more members of the congregation.

\section{The Reciprocal Nature of Storytelling}

By using a category like "homeless" we separate individuals and their experience from our own, hence stigmatising them. As Owa's sermon shows, mutual storytelling is one way in which this can be addressed. Nixon takes care to include his own story alongside those of his interviewees in Stories from the Street, highlighting his own experience of exclusion as a result of his liberal views on homosexuality. ${ }^{161}$ Courtenay relates an experience of justice by recounting how her inheritance was stolen from her. ${ }^{162}$ The telling of a story is important to people who are homeless because, as Nixon says, "it is by stories that we can reclaim our sense of self, and make sense of the 'narrative wreckage' of our lives ... in the disruption of homelessness." 163 I want to highlight two aspects of storytelling: the power that the storyteller has, and the power of the story itself.

Courtenay recognises that she is in her interviewees' hands, stating explicitly that she presents "their lives as they wished to tell them." 164 Nixon is aware that his interviewees curate their presentations, revealing "some true facts about themselves" but also modifying their stories for interview. ${ }^{165} \mathrm{He}$ acknowledges that he was unable to verify what he was told, so it was up to his interviewees what they include, what they omit and what they add or embellish. ${ }^{166} \mathrm{He}$ encounters considerable variety in narrative approach. Pete gives a sense of "managing his performance." He has "ordered the account of his life" giving the impression that he has "decided what to include and exclude and where humour might be suitable." He has "told it before and has in some ways even practised it." ${ }^{167}$ Fran, by contrast, is very confused, sometimes "appearing to contradict herself” and making "only a passing reference to potentially important events." 168 Gibbs believes that sometimes the presentation reflects the content, pointing out that the "fragmented, disturbed and disjointed" progression of Asif's interview "in some way mirrors the content of what he has to say." ${ }^{169}$ He also observes that dress can be part of the performance. For example, Mary

\footnotetext{
${ }^{161}$ Nixon, Stories, 70.

162 Courtenay, Four Feet Under, 12.

163 Nixon, Stories, 39.

${ }^{164}$ Courtenay, Four Feet Under, 348.

165 Nixon, Stories, 15.

$166 \mathrm{Id}, 43$.

${ }^{167} \mathrm{Id}, 108$.

$168 \mathrm{Id}, 72$.

${ }^{169}$ Gibbs, Staying in, 157.
} 
"wore large sun glasses and had her hair over her face, indicating that she wanted to remain anonymous." 170 With varying degrees of success, the interviewees are managing their visibility as they retell their stories. As Andrea Brighenti points out, managing our visibility "is a huge work that human beings do tirelessly." ${ }^{171}$ Eric Stoddart coined the term (in)visibility to capture this process, which he describes as "the dynamic of managing and negotiating our visibility in social space." 172 Erving Goffman sees our social life as a theatrical performance, in which we try to convey a specific impression to friends, colleagues and others that we meet. He points out that, like actors in a theatre, human beings need a private space, a "backstage" in which to manage their performance. ${ }^{173}$ People who are homeless lack this, living their whole lives in the public eye on the street or in the managed environment of a hostel. Retelling their story puts them in control, though as Frank showed its character can be changed to serve the purposes of subsequent retellers of that story.

\section{$\underline{\text { Narratives and Stigmatisation }}$}

What of the power of the story itself? The stories that people who are homeless tell break down the categorisation that leads to stigmatisation. Their chaos narratives are "hard to hear because they are too threatening," telling "how easily any of us could be sucked under." 174 They disclose how people who are homeless come from every level in society. More half of Nixon's interviewees would have presented as respectable and middle class for a large part of their lives. ${ }^{175}$ Pete presents a sobering account of how a stable life can collapse into homelessness. A dispute with his second wife over her habit of allowing drunken friends to sleep over at the house he funded from his pension led to him packing a suitcase, living in hostels and attempting suicide. ${ }^{176}$ Gibbs' interview with Asif "begins with a very brief glimpse of a carefree, happy time" when he was "helping in the family business." 177 Courtenay speaks to several individuals who once presented

${ }^{170} \mathrm{Id}, 170$.

171 Andrea Brighenti, "Visibility," Current Sociology 55, no. 3 (2016), 327, cited by Eric Stoddart, Theological Perspectives on a Surveillance Society (Abingdon: Routledge, 2016), 146.

${ }^{172}$ Stoddart, Theological Perspectives, 145.

${ }^{173}$ Erving Goffman, The Presentation of Self in Everyday Life (London: Penguin Books, 1990), 114.

${ }^{174}$ Frank, The Wounded Storyteller, 97-8.

${ }^{175}$ Nixon, Stories, 144.

${ }^{176}$ Id, 77.

177 Gibbs, Staying in, 155. 
as successful and respectable, such as Scott, a coach driver, Brad, a prosperous businessman and Patrick, a publican. ${ }^{178}$

Other interviews highlight how individuals fall into homelessness. Julie and Danni both came from broken homes, but this is not the reason they became homeless. They were made homeless because there was no provision available to them between the time they left their children's home at 17 , and the time that they became eligible to be housed by a housing association at $18 .{ }^{179}$ Asif was evicted from a centre because staff did not properly investigate a dispute and took the easy option of ejecting both parties. ${ }^{180}$ These examples show how individuals can be failed by the very structures that are put in place to help them.

\section{Summary}

As Nixon says, the diversity of the interviewees and their experiences revealed by their stories challenge the negative labelling and stereotyping of homeless people. ${ }^{181}$ This labelling can, as Gutierrez points out, lead to two pitfalls: "idealist or spiritualist approaches" which evade "a harsh and demanding reality" and "shallow analyses and programs of short-term effect initiated under the pretext of meeting immediate needs." 182 By contrast, as Francis points out "solidarity means much more than engaging in sporadic acts of generosity. It means thinking and acting in terms of community." "183 How can a parish church avoid the pitfalls Gutierrez warns against and become a genuine community that embraces both people who are homed and people who are homeless?

\section{Walking Humbly}

\section{$\underline{\text { Introduction }}$}

This brings us to the call to "walk humbly," which is fundamental to building a community, and is also the personal aspect of Dorr's framework. What is the purpose of a Church community?

What differentiates it from a charity offering practical help to people who are homeless, or a campaign addressing the structural causes of homelessness? Coming Home says that the Church "is not simply another social agency offering its solutions. Its primary loyalty, as St Augustine

\footnotetext{
178 Courtenay, Four Feet Under, 51, 85, 327.

${ }^{179}$ Nixon, Stories, 74, 71.

${ }^{180}$ Gibbs, Staying in, 156.

${ }^{181}$ Nixon, Stories, 144, 148.

182 Gutierrez, A Theology, 37.

${ }^{183}$ Francis, Fratelli, paragraph 116.
} 
insisted, is to the City of God, not the City of this World." 184 How is this loyalty reflected in the parish church?

I will start by examining how the Church of England's characterisation of its mission, as presented in Five Marks, sits with Dorr's framework. I will contrast this with the vision of the church as a community modelling God's love in the world presented by Francis and Forrester. I will move on to consider what church communities look like, using the two ways that Stephen Backhouse offers of imagining communities. I will point out that the parish system envisions the parish church as a neighbourhood, but to live out this model, it needs to fully include the most marginalised members of the community such as people who are homeless. I will conclude that it can only demonstrate its loyalty to the City of God by embracing their presence.

\section{Dorr and the Five Marks}

It is revealing to compare the Dorr model to the Five Marks of Mission which the Archbishop of York, Stephen Cottrell sees as "marks of discipleship" shaping the Christian life and the vocation of the Church of England. ${ }^{185}$ Seeking to transform unjust structures of society and striving to safeguard the integrity of creation are public aspects that correspond to Dorr's "act justly." Teaching, baptising and nurturing new believers and responding to human need with loving service are interpersonal, corresponding to Dorr's "loving tenderly." However, there is nothing in the Five Marks corresponding to the personal dimension of Dorr's model: "walking humbly." "To proclaim the Good News of the Kingdom," is the opposite. ${ }^{186}$ The verb proclaim implies a oneway conversation, suggesting that the Church can contribute to the spiritual growth of (for example) people who are homeless, but that there is no learning that can take place in the other direction.

Pope Francis points out in Fratelli Tutti that, by contrast, St Francis "did not wage a war of words aimed at imposing doctrines; he simply spread the love of God." 187 He offers a vision of a Church that "does not claim to compete with earthly powers" but offers herself as "a family among families" that is "open to bearing witness in today's world, open to faith, hope and love for the

184 Archbishop's Commission, Coming Home, 12.

185 Stephen Cottrell, A Vision for the Church of England in the 2020s, (London: Church House Publishing, 2020), 1 .

${ }^{186}$ MTAG, "Five Marks," 3.

${ }^{187}$ Francis, Fratelli, paragraph 4. 
Lord and for those whom he loves with a preferential love. A home with open doors." ${ }^{188}$ He sees the family as "the first place where the values of love and fraternity, togetherness and sharing, concern and care for others are lived out and handed on." ${ }^{189}$ How can these values find practical expression in a parish church?

In On Human Worth, Duncan Forrester points out that in some residential communities for the disabled "great efforts are made to emphasize that carers and those cared for are both primarily members of the community." ${ }^{190} \mathrm{He}$ writes that, "at the heart of the notion of equality lies the conviction that each person is of infinite and hence equal worth and should be treated as such." 191 We recognize others equal worth by "our attitude toward them, our treatment of them, our relationships with them and our regard for them, and also, rather more indirectly but very significantly, in the way a society and its distribution of resources of all sorts are organized." 192 He follows Tawney in declaring that equality "is a necessary condition for fellowship and true community," and that inequality "divides communities and creates all sorts of barriers of suspicion and rivalry. ${ }^{193} \mathrm{He}$ believes that an inclusive Church should strive to "affirm in practice the infinite worth of the neighbour" seeking to be "an inclusive community" that recognizes the equality before God of all who bear God's image. ${ }^{194}$ It is notable that Forrester here is in line with the views that emerge from Nixon's interviews with Julie and Charlie. ${ }^{195}$

"Neighbourhood" or "Herd"?

Can Francis' vision of the church as "a home with open doors" and Forrester's "inclusive community" be realised in the context of the parish church? A crucial point is that a parish is a community defined by a shared location. Stephen Backhouse suggests two ways of imagining communities: the "herd" and the "neighbourhood." Herds are arranged on a "like for like" principle, grouped around a common interest like a sports team, a hobby or a political party. The "herd mentality" says that "I need to relate to people who look like me, think like me or act like me." ${ }^{196}$ By contrast, neighbourhood relationships are arranged on an "unlike for unlike" basis. It

\footnotetext{
${ }^{188} \mathrm{Id}, 276$.

${ }^{189} \mathrm{Id}, 114$.

${ }^{190}$ Forrester, On Human, 6.

${ }^{191} \mathrm{Id}, 30$.

${ }^{192} \mathrm{Id}$.

${ }^{193}$ Id, 143, citing R. H. Tawney, Equality (London: Allen \& Unwin, 1964), 56.

${ }^{194} \mathrm{Id}, 195$.

${ }^{195}$ Nixon, Stories, 117.

${ }^{196}$ Backhouse, "Space and Neighbours," 46.
} 
is a collection of people who "are not congregating around what ideological or physical features they have in common, but by the fact that they share the same space and are alert to one another's presence." 197

Christian churches and other religious groups can take on the characteristics of herds, including only people who think like them by, for example, accepting a doctrine or theology. This emerges in Nixon's interviews. Fran's view of the church is coloured by her sister, a "born again Christian" who insists that "Fran is not properly a Christian until she has been re-baptised." 198 Julie points to Mormons and Jehovah's Witnesses who think "that they are the only ones going to heaven. They are really lost." 199

The parish system challenges the parish church to be a neighbourhood. As Coming Home points out, "clergy are given the 'cure of souls' of the whole parish - not just those who come to church." ${ }^{200}$ A parish has the opportunity to bring together "into a community of discourse, of faith and of sharing some of the richest and most powerful people" within the geographical area in which it is located with "some of the poorest and weakest." ${ }^{201}$ Forrester points out that the church is almost the only organisation whose membership extends from the poorest and most marginalized in society to the wealthiest and most powerful. ${ }^{202}$ He speaks of "the struggle of the church to be the church, a special kind of inclusive community.... that affirms and expresses the equal worth of all human beings." ${ }^{203}$ However there is an ever-present danger that it becomes a herd, implicitly excluding those who don't share the "features, values and passions" of its members. ${ }^{204}$ The word "proclaim" in the Five Marks therefore threatens the vision of the parish church as a neighbourhood. Even though eight of his eleven interviewees had significant exposure to Christian teaching either as a child or an adult, Nixon finds that "for the majority of those interviewed, there is little comprehension that the Christian story is good news for them." ${ }^{205}$ Seeking to impose a doctrine on them is characteristic of a herd mentality. A neighbour rather accepts and loves, and seeks to understand how their life story led them to where they are.

\footnotetext{
${ }^{197} \mathrm{Id}, 47$.

${ }^{198}$ Nixon, Stories, 116

199 Id, 117.

200 Archbishop's Commission, Coming Home, 10.

${ }^{201}$ Forrester, On Human, 212.

202 Id, 200.

$203 \mathrm{Id}, 212$.

204 Backhouse, "Space and Neighbours," 49.

205 Nixon, Stories, 148.
} 
How can a parish church avoid becoming a herd and take on the characteristics of a neighbourhood embracing all within its boundaries? The experience of those of Nixon's interviewees who have affiliated themselves with a local church community is illuminating. Although Pete turned his back on Church at 18, he has started to attend Church of England services regularly again. ${ }^{206}$ As Kimberly Bracken Long notes, it takes a lot of courage on the part of someone like Pete to thrust themselves "into the middle of ... well-behaved, well-educated, decently dressed Christians" and to claim a "place in the midst of the assembly." 207 Tim has tried the Church of England since becoming homeless, but has settled at his local Baptist Church, which "has never done anything to bring any fixed bearings on me. They took their own time to get used to me." His church has "given him a lot more strength." Interestingly, this strength has given him the confidence to perpetuate the lifestyle he leads now rather than change it to conform to the norm. He notes that "they've never brought any pressure to bear.",208

This acceptance is a characteristic of the Christian concept of a neighbour, which preserves the individuality of every person "in all of its elements without reducing their identity to any one element and without reference to any groups that they might belong to." ${ }^{209}$ Francis believes that the importance of the individual has been lost in society, especially in the light of our response to COVID, noting that "persons are no longer seen as a paramount value to be cared for and respected, especially when they are poor and disabled." 210 As Francis says, a community rests on respect for the dignity of others in all circumstances, "not because that dignity is something we have invented or imagined, but because human beings possess an intrinsic worth superior to that of material objects and contingent situations." 211 For church communities this means "finding ways to include those on the peripheries of life." 212

The Church as a Community

Therefore, it is the nature of the Church as a community that sets it apart. By contrast with a charity or a campaign, the Church is not defined by working towards a set of goals. As Leech says, the character of the Church is that of "a communion of persons, a way of being together

\footnotetext{
$206 \mathrm{Id}, 78$.

${ }^{207}$ Long, "When Homeless," 32.

208 Nixon, Stories, 116.

${ }^{209}$ Backhouse, "Space and Neighbours," 49.

${ }^{210}$ Francis, Fratelli, paragraph 18.

${ }^{211} \mathrm{Id}$, paragraph 213.

${ }^{212} \mathrm{Id}$, paragraph 215.
} 
which enables human personhood to flourish." 213 It is a response to the reality that "human beings were created for connection - connection to God and to one another" and "so need community to thrive." ${ }^{214}$ This connection is incomplete unless the community includes the marginalised. A parish church consisting exclusively of the comfortably-off restricts itself to one-way acts of charity directed at individuals outside that community. Francis' vision of the church as "a home with open doors" and Forrester's "inclusive community" can only be realised if the marginalised, such as people who are homeless, are present and fully embraced in the Church family. The gap between the community described by Francis and Forrester, and the reality of Church life that Bias to the Poor and the other reports uncover shows how (as Forrester says) "the church has been deeply penetrated and corrupted by the inequalities and divisions of the world" and has absorbed them "into its own structures and ways of working." It is "always in need of repentance and radical reformation." ${ }^{215}$ It is the structures and organisational culture of the Church that need transformation, as much as, if not more than, the lifestyles of people who are homeless. Harris and Sweetland point out that "there is a strong pull to remain comfortable and safe in our homes and churches, reinforced and justified by our societal norms and fears of the unknown 'other.' However, that is not the journey of radical discipleship that Jesus invites us on."216

How might the people interviewed by Nixon, Courtenay and Gibbs take members of a parish church forward on this journey? It is certainly apparent, through the interviews conducted by Nixon, Courtenay and Gibbs, that people who are homeless do think beyond their immediate plight and consider "the issues of life and death" seeking "insights into the meaning of human living." ${ }^{217}$ Nevertheless, as Growing Good and Coming Home show, the Church does not go beyond listening at the first level: their plight, and how it might be relieved. Within the Church, as within society, people who are homeless "lack the voice to make their experience count as worth knowing." 218 As Bias to the Poor shows, churchgoers, like others in society, use "their position of security" to insulate them "from the day to day realities of the life of the marginalized who remain 'invisible." ${ }^{219}$ This conflicts with Jesus' example. As Kopas says, "Jesus contradicts the notion

\footnotetext{
${ }^{213}$ Leech, The Sky, 34.

${ }^{214}$ Harris and Sweetland, "Community," 165.

${ }^{215}$ Forrester, On Human, 198.

${ }^{216}$ Harris and Sweetland, Community," 166.

${ }^{217}$ Leech, The Sky, 44.

${ }^{218}$ Kopas, "Outsiders," 117.

${ }^{219} \mathrm{Id}, 119$.
} 
that certain people should be outsiders by associating with unacceptable people, sinners and outcasts." ${ }^{220}$ When he encounters the marginalised, he helps them "discover personal and social values that transcend the standards of worth set in larger society." ${ }^{221}$ Reviewing the healings presented in Mark, Kopas notes that "each of these afflicted persons seeks out Jesus in the knowledge that there is more to a cure than the relief of physical discomfort." 222

This appears in the interviews. Edward, Tim and Asif didn't turn to Buddhism, Christianity and Islam to address their physical situation but to discover values and search for a cure beyond physical relief. Edward has learnt "not to be pessimistic and to give thanks" for example for the corner shop, the library and the day centre that he uses. ${ }^{223}$ For Tim, "homelessness has taught him the essentials of life" strengthening his Christian faith. ${ }^{224}$ Asif "is searching for forgiveness; he blames himself for not being able to prevent the death of his siblings, particularly his brother. These occurrences have stained his life and he is looking to be washed clean, for a new beginning." 225 All three know, as Kopas says "that their deepest identity cannot come from wealth, health, social status or religious structures." 226 Instead, it comes, for Asif and Tim "from God's unconditional acceptance" and for all three from "a sense of somehow being part of a larger whole."227

Kopas points out that "being an outsider makes a person vulnerable, but the very fact of that vulnerability provides context for greater awareness of dependence and interdependence.”228 This is apparent in the interviews. For Edward this interdependence emerges in a positive sense. He recognises that he benefits from street lighting provided and paid for by others. For Asif it is negative. He was powerless in the face of aggression from others. Tim acknowledges his dependence on God as "someone I've been able to turn round to in prayer" in sticky positions. ${ }^{229}$ Owa articulates a similar thought in her sermon: "we should pray without ceasing and hope in God's faithfulness, believing that God is able to see us through no matter what happens." ${ }^{230}$ From

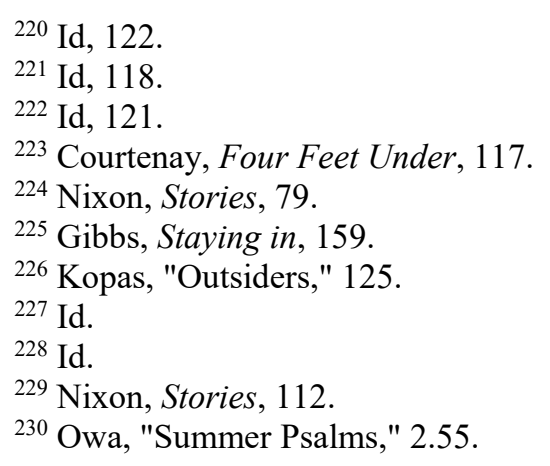


the perspective of their marginalisation, Edward, Asif, Tim and Owa have come to know that "selfcreated security is an illusion." 231 This is an important lesson that outsiders such as people who are homeless can offer insiders. Kopas puts it like this: "what we have to learn from outsiders touches our deepest fears and hopes. The marginalized teach us first by asking us to face our fears and hopes. Where do you get your security? Can you listen to perspectives other than your own?"232

For insiders to hear this means addressing the central challenge that people who are homeless pose to the parish church. Can it offer full inclusion? Can it embrace them with hospitality rather than accept them with tolerance? To do so requires listening at the second level as well as the first. Kopas concludes that when "“insiders' learn to enter into genuine conversation with 'outsiders' they too may find God present again in their midst." 233 Button comments, "When we make space for others, when we find a place of belonging with others, there in that place God also makes his home."234

\section{Summary}

As Sweetland and Harris note "working with people on the fringes is messy, and, as a church, that's what we're called to do." 235 For them, "it is the complexity of people with strongly held views, oddly formed habits and the ability to display irrational or deliberately hurtful behaviour that makes community so vital and yet so challenging and risky." 236 The question that they pose is "how can the Church courageously give away, share and build community?"237 To address it, the Church needs, in Nixon's words "the humility which understands that the wealthy need to be alongside the poor more than the poor need the wealthy." ${ }^{238}$ As Francis says, this is because "they have another way of looking at things; they see aspects of reality that are invisible to the centres of power." ${ }^{239}$ Courtenay concurs saying that there is every reason to listen to someone who is homeless because "they have a lot to say that is worth hearing." 240

\footnotetext{
${ }^{231}$ Kopas, "Outsiders," 125.

${ }^{232} \mathrm{Id}, 126$.

${ }^{233}$ Kopas, "Outsiders," 126.

234 Button, "Where do I," 160.

${ }^{235}$ Harris and Sweetland, "Community," 166.

${ }^{236} \mathrm{Id}, 172$.

${ }^{237}$ Id.

238 Nixon, Stories, 159.

${ }^{239}$ Francis, Fratelli, 215.

${ }^{240}$ Courtenay, Four Feet Under, 236.
} 


\section{Conclusion}

Coming Home is commendable in that it points to the structural reasons behind the housing crisis in general and homelessness in particular. However, it misses the vision of community that Francis articulates in Fratelli Tutti. When it uses sentences like "the building and nurturing of inclusive communities really matters to us," there is little follow-through on how this thinking might transform the parish church. ${ }^{241}$ Rather the focus is on initiatives for "meeting housing need." 242 Its enthusiasm, visible in particular in the restitution narratives of successful projects, threatens to oppress church members by its implicit call to go and do likewise. This is particularly evident when Coming Home falls into corporate speak. For example it points to the "able and committed builders, planners, architects and housing professionals" amongst its membership. ${ }^{243}$ Here, it threatens to lose sight of the fact that these individuals aren't "simply units of labour" but "limbs and organs of a living body." ${ }^{244}$ An inclusive community should not regard professionals amongst its members as units of expertise any more than it should see people who are homeless as buckets of need. That thinking oppresses both. As Harris and Sweetland point out, "everyone is a work in progress; needing connection to shape and encourage us in our faith, grow our vision, deepen our identity, and hear God for each other." ${ }^{245}$ For this reason, as Francis says, "no-one is saved alone; we can only be saved together." 246 That is why it is important to regard people who are homeless not as "others" or "strangers" but "seekers and believers like the rest of us." 247

Drawing this together, Nixon, Courtenay and Gibbs in their interviews demonstrated that listening is essential, not just because it helps people who are homeless but also because their views can help us. Unfortunately, the reports that I have reviewed show that the Church has been corrupted, and its attitudes to these people reflect those in the world. Only if people who are homeless themselves are given a voice can the Church be transformed. By hearing their voices alongside those of formal theologians, I have demonstrated that their thinking has maturity and can be taken seriously. Unfortunately, the Church, like society, tends to stigmatise them, reinforcing this stigmatisation through one-way acts of charitable giving. Nixon and Owa show that mutual

\footnotetext{
${ }^{241}$ Archbishop's Commission, Coming Home, 67.

$242 \mathrm{Id}, 54$.

${ }^{243} \mathrm{Id}, 36$.

${ }^{244}$ Leech, The Sky, 34.

${ }^{245}$ Harris and Sweetland, "Community," 170.

${ }^{246}$ Francis, Fratelli, paragraph 32.

${ }^{247}$ Long, "When Homeless," 33.
} 
storytelling can overcome this negative stereotyping. Leech points to the "inextricable link between the response to poor people and the humanity of the whole community." ${ }^{248}$ The presence of people who are homeless within that community, per Leech, has the effect of restoring its humanity. Coming Home suggests that the Church has a part to play in realising "housing that gives a taste of the heavenly city." 249 In fact, it has the opportunity to achieve a bigger vision: of being a community that gives a taste of this heavenly city. By fully including people who are homeless, showing hospitality and being open to being transformed by them, the parish church can become "an exemplary community," an instrument "not so much for bringing or building God's Reign as for spreading throughout society the values, social structures and attitudes which are characteristic of the Reign of God." 250

${ }^{248}$ Leech, The Sky, 248.

${ }^{249}$ Archbishop's Commission, Coming Home, 64

${ }^{250}$ Forrester, On Human, 196. 


\section{BIBLIOGRAPHY}

Archbishop's Commission on Housing, Church and Community. Coming Home: Tackling the Housing Crisis Together. London: Church House Publishing, 2021.

Backhouse, Stephen. "Space and Neighbours." In Coming Home: A Theology of Housing, edited by Malcolm Brown and Graham Tomlin, 38-52. London: Church House Publishing, 2020.

Brighenti, Andrea. "Visibility." Current Sociology 55, no. 3 (2016): 323-42.

Brown, Malcolm. "Housing, Church and Community - and Christian Theology." In Coming Home: A Theology of Housing, edited by Malcolm Brown and Graham Tomlin, 53-74. London: Church House Publishing, 2020.

Button, Christopher. "Where Do I Belong? Rethinking Homelessness." Practical Theology 11, no. 2 (2018): 153-63.

Cameron, Helen, Deborah Bhatti, Catherine Duce, James Sweeney and Clare Watkins. Talking About God in Practice: Theological Action Research and Practical Theology. London: SCM Press, 2010.

Chamberlain, Chris and David Mackenzie. "Understanding Contemporary Homelessness: Issues of Definition and Meaning." Australian Journal of Social Issues 27(4) (November 1992): 274-97.

Church Urban Fund. "Key Findings from and Commentary on the CUF Survey." Accessed 10 December 2020. https://cuf.org.uk/uploads/resources/Key-findings-from-andcommentaryon-the-CUF-survey.pdf.

Church Urban Fund. "Key Findings: Bias to the Poor? Christian Attitudes to Poverty in This Country." Accessed 10 December 2020. https://cuf.org.uk/uploads/ resources/Bias_to_the_poor_Jan2012.pdf.

Commission on Urban Life and Faith. Faithful Cities: A Call for Celebration, Vision and Justice. London: Church House Publishing, 2006.

Courtenay, Tamsen. Four Feet Under. London: Unbound, 2018.

Dorr, Donal. Integral Spirituality: Resources for Community, Justice, Peace and the Earth. Gill and Macmillan: Dublin, 1990.

Forrester, Duncan. On Human Worth. London: SCM Press, 2001.

Francis. Fratelli Tutti: Encyclical Letter on Fraternity and Friendship. Vatican: The Vatican Press, 2020.

Frank, Arthur. The Wounded Storyteller. Chicago: The University of Chicago Press, 2013.

Gibbs, Raelton. Staying in the Shadows: Faith, Homelessness and Troubled Lives. University of East London and Tavistock and Portman NHS Foundation Trust (London: 2011).

Goffman, Erving. The Presentation of Self in Everyday Life. London: Penguin Books, 1990.

Gutierrez, Gustavo. A Theology of Liberation. Translated by Sister Caridad Inda and John Eagleson. London: SCM Press, 1974. 
Harris, Nicola and Jez Sweetland. "Community, Hospitality and Space-Making." In Coming Home: A Theology of Housing, edited by Malcolm Brown and Graham Tomlin, 165-84. London: Church House Publishing, 2020.

Housing Justice. "Homeless Sunday Video (London)." Accessed 10 December 2020. https://www.youtube.com/watch?v=lLBxET70_2s\&feature=youtu.be.

December 2020.

Video (National)." Accessed 10

https://www.youtube.com/watch?v=f6u2DGmtDPs\&feature=youtu.be.

Kopas, Jane. "Outsiders in the Gospels: Marginality as a Source of Knowledge." The Way (1993 vol 33 no 2): 117-26.

Leech, Kenneth. The Sky Is Red. London: Darton, Longman and Todd, 1997.

Long, Kimberly Bracken. "In from the Street: When Homeless Christians Join the Worshipping Assembly." Journal for Preachers (2008): 31-40.

Mission Theology Advisory Group. "The Five Marks of Mission." The Church of England, 2017. Accessed 10 December 2020. https://www.churchofengland.org/ sites/default/files/201711/MTAG\%20The\%205\%20Marks\%20Of\%20Mission.pdf.

Moltmann, Jurgen. Experiences in Theology: Ways and Forms of Christian Theology. Fortress Press, 2000.

Nixon, David. Stories from the Street: A Theology of Homelessness. Farnham, Surrey: Ashgate Publishing, 2013.

Owa, Bosede. "Summer Psalms - Psalm 71." Accessed 3 December 2020.

Rich, Hannah. Growing Good: Growth, Social Action and Discipleship in the Church of England. London: Theos, 2020.

Sefton, Tom and Heather Buckingham. Church in Action: A National Survey. London: The Church of England and the Church Urban Fund, 2017.

Stivers, Laura. Disrupting Homelessness: Alternative Christian Approaches. Fortress Press: Minneapolis, 2011.

Stoddart, Eric. Theological Perspectives on a Surveillance Society. Abingdon: Routledge, 2016.

Thomas, Grace. "Grace's Story." Accessed December 11 2020. https://youtu.be/ncJsJQLCsMQ.

Tomlin, Graham. "Coming Home: A Theology of Housing and Community." In Coming Home: A Theology of Housing, edited by Malcolm Brown and Graham Tomlin, 1-16. London: Church House Publishing, 2020.

Welby, Justin. Reimagining Britain: Foundations for Hope. London: Bloomsury, 2018.

Wickham, Rob. $\quad$ "Homeless Sunday Sermon." Accessed 10 December 2020. https://www.dropbox.com/s/v7ekwnw2j10yraz/Sermon\%20for\%20H\%20Sunday\%20.mp $4 ? \mathrm{dl}=0$. 